\title{
The Founding and Early Years of the National Association for the Advancement of Colored People in Des Moines, 1915-1930
}

\author{
JACK LUFKIN
}

Nationwide and in Iowa the status of Negroes, and relations between blacks and whites, reached a low point from about 1890 to the 1930s. Backsliding from the advances achieved during the Civil War and Reconstruction, blacks had become subject to racially-inspired social, political, and economic sanctions which deflected them further from mainstream American society. These sanctions stemmed from beliefs commonly held by whites that Negroes were biologically inferior beings. Consequently, Negroes occupied the substratum of American society.

The National Association for the Advancement of Colored People (NAACP) formed in 1909 during this nadir period for blacks, and emerged as one of the most effective nationwide organizations to combat racism and discrimination. The Des Moines branch organized in 1915. Its members immediately spearheaded the local drive for racial equality by molding small, disparate protest groups and individuals-black and whiteinto the most potent political organization of its kind in Iowa. Although the Des Moines NAACP did not prevent many dispiriting rebuffs suffered by the city's black citizens, it did achieve some important successes that paved the way for modern civil 


\section{The Annals of Iowa}

rights agitation. The activities of this organization provided articulation of many of the national NAACP's concerns and goals, and gave local blacks a chance to apply leadership skills.

Negroes' deteriorating status at the end of the nineteenth century constituted a phenomenon of widespread proportions. Not only were blacks victims of the blatant brand of racism practiced in the former Confederate states, blacks also suffered from northern ambivalence and hostility. In spite of the Fourteenth Amendment's guarantee of full citizenship rights for blacks, the law was either rarely enforced or perversely distorted with the result that few blacks could hold public office or even vote. By 1890 the status of the average Negro in American society was only marginally better than slavery.

Legal measures and court decisions reflected national patterns of discrimination. The famous Plessy v. Ferguson Supreme Court decision of 1896 validated the separate but equal clause, thus legitimizing and encouraging a flood of Jim Crow segregation laws in the South. In most large northern cities, including Des Moines, unwritten Jim Crow practices were rigidly followed, especially in private businesses and in many public places.

In facing these conditions, some blacks responded militantly; most adhered to the beliefs propounded by the preeminent Negro leader in America at this time, Booker T. Washington. He urged his brethren to eschew politics and pursue policies of economic self-help and self-reliance, industrial education, and social accommodation. Washington posited that a rising economic status for black people would serve as a catalyst pulling Negroes toward social and political equality while eliminating the strife of continuing confrontations. These proposals, though actively pursued by many blacks, failed to halt or even significantly mitigate unrelenting segregation and discrimination. ${ }^{1}$

${ }^{1}$ The best two single volume studies of Negroes in America which pull together all the major sources are: August Meier and Elliott Rudwick, From Plantation to Ghetto (New York: Hill and Wang, 1976) and John Hope Franklin, From Slavery to Freedom (New York: Knopf, 1947). The leadership of Booker T. Washington is discussed in August Meier, Negro Thought in America, 1880-1915 (Ann Arbor: University of Michigan Press, 1964). Louis 
Many northern blacks in the waning years of the nineteenth century applied Washington's principles in an urban industrial setting. During and immediately following World War I they were joined by waves of southern blacks migrating north to larger cities in hopes of finding a better life. But, as their numbers swelled, white hostility became more pronounced and blacks found themselves pushed into densely populated ghettos, cut off from the social, political, and economic life of the cities that had beckoned them. Most urban blacks held menial, unskilled jobs in heavy industry, or were domestic servants. ${ }^{2}$

Negroes in Des Moines from the 1880 s to the 1930 s felt the humiliation of segregation and discrimination. Between 1880 and 1930 they made up between three and five percent of the city's population. Although one of the largest minority groups in the city, blacks wielded little political influence. Only one black was ever elected to public office: Frank Blagburn as market master in 1899. As market master, Blagburn was given the responsibility for the orderly operation of the city market house and for renting space to farmers wishing to sell their products. Black leaders occasionally received other innocuous political posts within the Republican party, but socially the races rarely mingled. Even if a clearly defined ghetto did not form in the pattern of Chicago and Detroit, blacks in Des Moines found they were excluded from living in certain sections of the city. The average black held a menial job and could hope for little or no upward

R. Harlan's Booker T. Washington: The Making of a Black Leader, 1856-1901 (Oxford: Oxford University Press, 1972) is the most recent biography of Washington and provides valuable background of the Negro leadership movement during Washington's time.

${ }^{2}$ No work has definitely chronicled the urban movement of Negroes in northern and midwestern cities, but many works have detailed the development of Negro communities in individual cities. Among the best are: Allan Spear, Black Chicago: The Making of a Negro Ghetto, 1890-1920 (Chicago: University of Chicago Press, 1967); Gilbert Osofsky, Harlem: The Making of $a$ Ghetto (New York: Harper Press, 1966); Kenneth Kusmer, A Ghetto Takes Shape: Black Cleveland, 1870-1930 (Urbana: University of Illinois Press, 1975); David Katzman, Before the Ghetto: Black Detroit in the Nineteenth Century (Urbana: University of Illinois Press, 1973). 
mobility socially, economically, or politically. Generally, blacks in Iowa's capital received the same treatment as their counterparts in the heavily industrialized cities convulsed by more violent racial tensions. ${ }^{3}$

The conditions affecting blacks in Des Moines and the nation, and the apparent failure of Booker T. Washington's policies, caused a dissident group of former Washington supporters to arise. The chief leader of this new movement was one of Harvard University's first Negroes to earn a Ph.D.: W.E.B. Dubois. Dubois denounced Booker T. Washington's advocacy of political neutrality. To demonstrate his political activism Dubois helped in 1905 to organize the Niagara Movement, a program designed to institute full voting rights for Negroes. Ironically this drive to enforce enfranchisement legislation failed largely because Washington, still America's most visible and respected black leader, opposed the movement. It was not until Dubois and other black leaders teamed with white progressives that Negroes found their most effective organization to combat discrimination. One organization prominently involved in the modern civil rights movement began during this trying period for American blacks. ${ }^{4}$

Largely in reaction to the condition of Negroes nationwide and to the rise of lynching in the South, the NAACP formed in 1909 in New York. Whites actually initiated the organization's formation, though it did gain impetus from black leaders like Dubois and Boston protest editor William Monroe Trotter. Initial white support came from Jewish leaders, such as Joel Spingarn; from Unitarian clergymen; and from a host of progressive political activists, including New Republic editor

${ }^{3}$ The Iowa Bystander provides good background on the discriminatory conditions under which black people lived in Des Moines from 1897 to 1921; State Census of Iowa manuscripts, 1915, 1925, Historical Building, Des Moines; Leola Nelson Bergmann, The Negro in Iowa (Iowa City: State Historical Society of Iowa, 1969); "The Negro in Iowa," reports and interviews compiled by the Iowa Writers' Project of the Works Progress Administration, circa 1935, Historical Building, Des Moines; G. Victor Cools, 'The Negro in Typical Communities of Iowa" (M.A. thesis, University of Iowa, 1918).

${ }^{4} \mathrm{~A}$ discussion of the ideological rift between Washington and Dubois occurs in Meier, Negro Thought. Another contrast is offered in works by the two 
Oswald Garrison Villard, wealthy New York social activist Mary White Ovington, Hull House founder Jane Addams, noted attorneys like Clarence Darrow, and Lillian Wald, founder of the world's first public health center. Dubois represented the organization's black leadership and became editor of the Association's official publication, the Crisis. But from its beginning the NAACP pursued the goal of enlisting notable white members in order to build prestige and secure adequate operating funds. An interracial leadership had the advantage of promoting a better understanding between the races and proved more effective in surmounting widespread institutional barriers to integration. ${ }^{5}$

This leadership and membership formula worked well during the Association's early years as both white and black leaders headed branch offices mainly in larger cities along the east coast. The organization had expanded so much that by 1919 over three hundred cities nationwide had formed local organizations totaling over 91,000 members. Approximately ninety percent of the membership was black. Under the guidance of the national chapter, these local branch organizations sought to lessen the more harmful manifestations of racism by seeking legal redress for unjustly prosecuted Negroes. Local unit members also established bureaus of information, organized mass and parlor meetings, and held memorial exercises to honor either past Negro leaders or noteworthy accomplishments of American blacks. Local branch leaders also pursued the assigned task of studying local race conditions, influencing the white press in a manner favorable to blacks, pressing for the enforcement of civil rights, and establishing all-black civic centers. ${ }^{6}$

During 1914 and 1915 the NAACP's national board chairman, Joel Spingarn, launched two western trips in an attempt to form

Negro leaders: Booker T. Washington, Up from Slavery (New York: Bantam, 1901) and W. E. Burghardt Dubois, The Souls of Black Folk (Greenwich, CT: Fawcett, 1903).

${ }^{5}$ Charles Flint Kellogg, NAACP: A History of the National Association for the Advancement of Colored People, 2 vols. (Baltimore: Johns Hopkins Press, 1967), 1: 110-120, 125.

'Ibid., pp. 120, 137. 
new branches and increase the membership of existing ones. In January of 1915, Des Moines was on his itinerary. Months before Spingarn's projected arrival, a local Negro attorney and community leader, S. Joe Brown, received literature from the national secretary explaining the purposes and plans of the organization. The letter included a request for organizing a membership branch in the city and announced Spingarn's visit. Brown and his wife, Sue, also an active leader in Des Moines' Negro community, responded to the request and gathered twenty-five initial committee members to help finance the visit. The local branch counted thirty-five charter members. This number swelled following the first open meeting held on the day of Spingarn's stop. Governor George W. Clarke addressed the audience and introduced the guest from New York. A progressive Republican, Clarke paid tribute to the accomplishments of the race and expressed hope that one day blacks would enjoy equal opportunities in Iowa. The remainder of the program, including Spingarn's speech, was held in the Corinthian Baptist Church, the largest and one of the most influential black churches in the city. The convocation drew eight hundred persons, mostly blacks. Thus, with the governor's attendance and support at the first meeting, the Des Moines branch gained immediate local attention and prestige, and within days after the meeting ended, over one hundred persons joined. The branch's first president, S. Joe Brown, who served until 1917, led a drive that resulted in the membership of two hundred by September $1915 .^{7}$

Considering the increase in membership, the first year proved successful. Prominent local whites joined this branch in accordance with the national organization's strategy. The governor paid his dues as did a number of high ranking city officials,

"S. Joe Brown, "History of the Des Moines Branch, National Association for the Advancement of Colored People, 1927" (Des Moines: Bystander Press, 1927), Historical Building, Des Moines, pp. 2-3; Des Moines Register and Leader, 20 January 1915, p. 12; Ibid., 21 January 1915, p. 4; Bystander, 22 January 1915, p. 1; Ibid., 3 December 1915, p. 1; Ibid., 24 September 1915, p. 1; Herbert Aptheker, ed., A Documentary History of the Negro People in the United States, 1910-1932 (Secaucus, New Jersey; Citadel Press, 1973), p. 161. 
prominent attorneys, and civic leaders, many of whom did not take an active part. ${ }^{8}$ Just over a year after the Des Moines NAACP's inception, the national headquarters sent a congratulatory letter to Brown and his fellow members expressing pleasure over the progress made in the membership drive. There was good reason to congratulate Brown; compared to local branches nationwide, the Des Moines branch ranked ninth in size, including more members than its counterpart in Kansas City. Chicago was probably the only city in the Midwest with a larger NAACP membership than Des Moines in $1916 .{ }^{9}$

Despite this initial success, drives for even larger membership rolls occupied the energies of local NAACP leaders. By 1918 the Iowa Bystander, a black owned and operated newspaper based in Des Moines, reported the enrollment of about 350 members still including Governor Clarke as well as Des Moines' mayor, Tom Fairweather; three justices of the state Supreme Court; other state officials; and city councilmen. This surge continued as membership climbed over five hundred by 1919. But the drive was not confined to Des Moines. The capital city branch also assumed the responsibility of promoting the formation of branches in other Iowa cities. S. Joe Brown, the state's district organizer in 1920, laid the groundwork for the chapter that formed in Centerville. ${ }^{10}$ Additional Iowa branches formed in Council Bluffs, Davenport, Waterloo, and Cedar Rapids during the 1920 s. ${ }^{11}$

\section{Activities of the Des Moines NAACP, in accordance with the policies formulated by the national directors, included educational programs, youth organizations, and legal action. Educational program promoters aimed their efforts at whites equally as much as blacks. These programs were frequently}

'Throughout 1915 and 1916 the Bystander periodically listed the names and positions of new NAACP members.

'Bystander, 10 March 1916, p. 1.

${ }^{10}$ Bystander, 20 December 1918, p. 5; Ibid., 28 March 1919, p. 3; Ibid., 18 June 1920 , p. 1.

${ }^{11}$ Director of branches to Sue Brown, 27 May 1926, Records of the NAACP, Des Moines, Iowa, Box G-68, folder 2, Manuscript Division, Library of Congress (hereafter cited as RNAACP). 


\section{The Annals of Iowa}

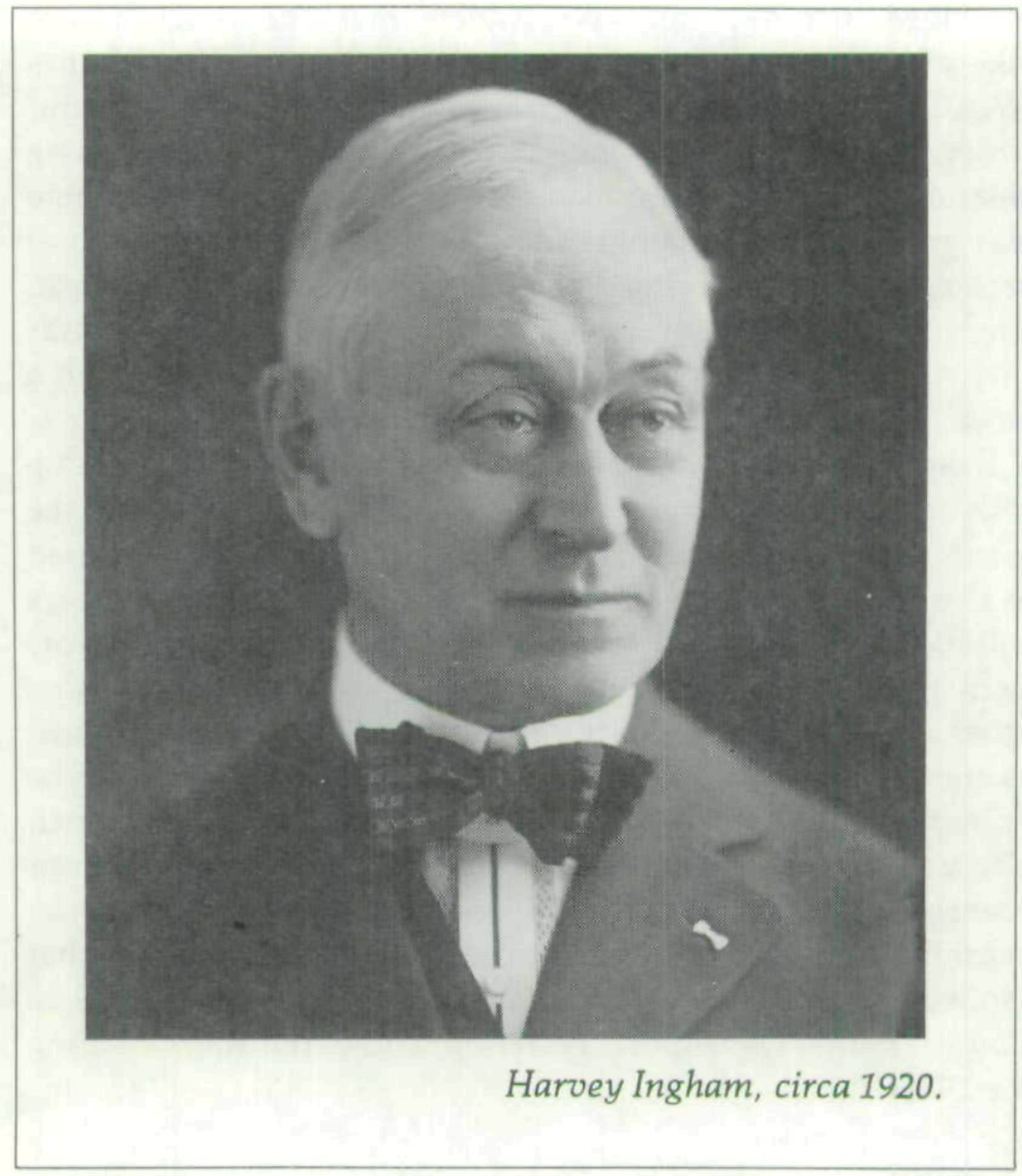

aimed at dispelling a negative, stereotypic image of blacks as inferior, kowtowing, burlesque figures, or worse, savages. Since the majority of whites had little or no contact with blacks, the task of changing white perceptions was highly difficult, if not impossible. One tactic was to enlist the services of prominent whites. Branch leaders invited them to speak on behalf of Negro rights hoping that the example set by certain white leaders championing black causes would persuade other whites to join the branch and give it added influence and prestige.

The Des Moines NAACP achieved only limited success in attracting whites to the organization, but it did pursue activities 
geared towards projecting a positive image of Negroes. In working with Negro members and the entire Negro community in Des Moines, the organization's educational arm stressed the need to develop skillful leadership qualities, and recognized the need for Negro leaders to sharpen their skills in asserting fuller citizenship rights.

In 1921 the city Chamber of Commerce responded favorably to a request by branch members to endorse another membership drive. A local ministerial association also endorsed the NAACP's efforts. Perhaps the most important expression of support, from the standpoint of prestige, came once again from the state's governor, Nate Kendall. Governor Kendall addressed a convocation of city ministers and other clergymen at the allblack Maple Street Baptist Church. He urged them to support the NAACP beyond a verbal endorsement. In a written proclamation the governor encouraged the clergy to become active members of the organization. Terming the NAACP the most potent force in solving the city's racial problems, Kendall admirably lent his support to the aims of the NAACP's educational committee. ${ }^{12}$

The most effective white civic leader to crusade for the NAACP's educational program was Harvey Ingham, editor of the Des Moines Register and Leader. A member since World War I, Ingham was one of the NAACP's most articulate and powerful backers. His prominence and local popularity injected the educational program with much needed enthusiasm and publicity. As editor of a leading white newspaper he saw to it that fair, if still limited, stories concerning Negroes came off his presses.

Ingham participated in the 1920 educational drive; his efforts helped keep the fledgling drive on its feet. The editor attacked Capital City Commerical College in Des Moines for refusing to admit black students. He condemned the school's policy in a speech delivered at the college. A Bystander writer observed that as a result of the speech the school's officials considered changing their discriminatory policy. Ingham, with the indefatigable S. Joe Brown, followed a veritable lecture circuit, ad-

${ }^{12}$ Bystander, 19 May 1921, p. 1. 
dressing a variety of civic groups in Des Moines during 1920. The organization reaped new applications for membership wherever Brown and Ingham spoke. Among prominent white educators who joined at this time were Edgar Harlan, curator of the Iowa Historical Department, and the city superintendent of the public school extension department. ${ }^{13}$

Aside from direct involvement in NAACP affairs, Ingham assisted the NAACP quest for achieving civil rights through his newspaper. In editorials he castigated the nationally resurgent $\mathrm{Ku}$ Klux Klan in uncompromising terms. He especially disapproved of the Klan's tendency to take the law into its own hands, which stood in contrast to the NAACP's primary protest strategy of promulgating law suits. Another example of Ingham's invaluable help, a purely symbolic gesture that black leaders nonetheless considered highly important, was the editor's willingness to capitalize the word Negro in the Register and Leader and encouragement to the city's other white-owned newspapers to do the same. The organization considered this gesture a breakthrough, a first step in changing whites' image of the Negro. In 1929 Ingham received a duly-earned award as the branch's honorary president. ${ }^{14}$

Even though NAACP leaders in Des Moines directed educational efforts toward soliciting support and financial assistance from the city's white populace, they did not ignore black members. Negroes filled the majority of the Association's general membership and were, in the main, responsible for daily organizational tasks. S. Joe and Sue Brown sponsored many programs directed at black members and S. Joe performed basically the same tasks as Ingham in giving a host of speeches. He also organized groups or seminars attended mainly by blacks. Seminar participants discussed problems blacks regularly encountered and suggested possible solutions. Other black leaders involved in creating similar forums were Elbert Hall, Brown's successor, and James B. Morris, an attorney who served effectively

${ }^{13}$ Bystander, 20 February 1920, p. 3.

${ }^{14}$ George Mills, Harvey Ingham and Gardner Cowles, Sr.: Things Don't Just Happen (Ames: Iowa State University Press, 1977), p. 48; Memorandum, undated, RNAACP; Des Moines Capital, 9 November 1929. 
as president of the NAACP from 1920 until 1923. Hall helped organize a drama club which staged allegorical plays about the NAACP designed to boost the black viewers' morale and selfesteem. The national organization even recognized the Des Moines branch, congratulating Hall for promoting interracial understanding. The Crisis also reported the club's activities. Hall sent local representatives to the NAACP-sponsored National Anti-Lynching Conference in the early 1920s. ${ }^{15}$

In addition to promoting educational programs, the Des Moines NAACP, from its beginning, attempted to appeal to young Negroes. The Des Moines NAACP Junior Chapter was established around 1922 by Sue Brown. Robert W. Bagnall, the national director of branches, forwarded Mrs. Brown a hearty letter of congratulations for her efforts. Bagnall reiterated the national organization's continuing desire to not only increase its membership, but also to promote participation by all segments of Negro society. Mrs. Brown, who became the branch president in 1925, unselfishly devoted hours of her time to the Junior Chapter. She also received help from Ingham who commended the juniors in a Register editorial. Partially as a result of Ingham's influence and Mrs. Brown's efforts to favorably publicize youth activities, blacks won another symbolic concession from one white group. In 1924 leaders of the branch rejoiced to find a dairy company's advertisement in the Register picturing a Negro baby. This was probably the first time in the city's history, said an NAACP leader, that an advertisement did not intend to depict a black in derogatory fashion. ${ }^{16}$

The Junior Chapter put on one of its most important events in 1924. Its members staged a drama entitled "The Awakening" at the city's Lincoln Theatre. In a report to the national office concerning local events, a Des Moines member wrote to the director of branches that this play served as one of the most effective appeals for the NAACP in the local branch's history. The play,

${ }^{15}$ Brown, "History of the Des Moines Branch," p. 5.

${ }^{16}$ Bagnall to Sue Brown, 28 March 1923, Box G-68, folder 1, RNAACP; Bagnall to Sue Brown, 17 December 1923, Box G-68, folder 1, RNAACP; Bagnall to Sue Brown, 25 February 1924, Box G-68, folder 1, RNAACP. 
written by Mary White Ovington, had an allegorical plot whose sole purpose was to define the Association's goals. ${ }^{17}$

The NAACP's emphasis upon youth fostered the formation of the Negro YMCA in Des Moines during the early 1920s. This group inaugurated a series of mass meetings and speeches similar to those of the educational committee and tried to attract speakers of international fame who could publicize the quest for equal rights. In 1924 a noted missionary, Sherwood Eddy, came to Des Moines and spoke to a few thousand people, mostly whites. Like Ingham, Eddy denounced the Ku Klux Klan. An NAACP member averred that his speech " ... will have a profound effect in favor of colored people in Des Moines. It will do much to allay the rising tide of prejudice engendered by the untiring efforts of the local Klan organization."18

This statement, if overzealous, certainly reflected the excitement and enthusiasm with which local blacks received the NAACP. Never before had black leaders been so involved in upgrading the image of their race, and although Booker T. Washington did not endorse this organization, its branch in Des Moines promoted Washington's ideals of self-help, confidence, and self-esteem with some success. Even if whites failed to effect many real, meaningful changes in the black community, more white leaders became attentive to Negroes' needs as a result of agitation and education from the NAACP. However slight the changes, they were sufficient to maintain the needed momentum toward achieving some civil rights reforms, chiefly accomplished through law suits. Even though the NAACP's first suit failed, it showed more white support than blacks suspected.

\section{LESS THAN A YEAR after its founding, the Des Moines NAACP's legal committee faced its first court test. S. Joe Brown called it a "herculean task." One of America's greatest movie directors, D. W. Griffith, introduced Hollywood's first blockbuster full feature film, the epic Birth of a Nation, in 1915. Although it}

${ }^{17}$ Des Moines NAACP secretary's report to the national office, 27 February 1924, Box G-68, folder 1, RNAACP.

${ }^{18} \mathrm{Ibid}$. 
revolutionized the motion picture industry, the movie contained a number of scenes depicting blacks in uncomplimentary and subservient roles. Styled after a novel written ten years earlier entitled The Clansman, the motion picture's content angered the NAACP's national leadership. They denounced it as slanderous and instructed members of local branches to prevent its showing. ${ }^{19} \mathrm{~A}$ Des Moines theatre scheduled the movie's debut in April 1916. By January of that year the forces opposing its showing began agitating. With representatives of the Iowa Purity Association, NAACP attorneys and other members of the legal redress committee issued a formal protest. A city councilman was also a member of the redress committee. In response, Mayor John MacVicar promised to discuss the demonstrators' demand with the city superintendent of safety. He also pledged support in attempting to secure the theatre owner's voluntary withdrawal of the movie. ${ }^{20}$

The NAACP received further support from other unnamed city groups as sentiment against the movie's showing on racial grounds mounted. Editors of the Des Moines Capital and the National Prohibitor opposed the movie and tacitly supported the NAACP's efforts. The local Grand Army of the Republic and the White City Federation of Women's Clubs also denounced the movie. Faced with this pressure, the mayor and the superintendent of public safety acted. They persuaded the theatre manager to show the movie privately to interested city officials and representatives of the protest groups before its public opening. The mayor hoped he could fairly determine if its contents warranted censorship. ${ }^{21}$

Besides exerting public pressure, the legal redress committee also had a solid legal point to argue, based on statutory precedent. The legal precedent stemmed from a 1907 city ordinance passed in response to The Clansman which was staged as a play that year in Des Moines. S. Joe Brown had written the ordinance that barred the play from returning to the city. NAACP attorneys argued that Birth of a Nation's plot so resembled

${ }^{19}$ Brown, "History of the Des Moines Branch," p. 3; Kellogg, NAACP p. 21.

${ }^{20}$ Bystander, 14 January 1916, p. 1.

${ }^{21}$ Ibid. 


\section{The Annals of Iowa}

the play that to allow its showing was, in effect, allowing The Clansman to return. NAACP attorneys initially protested the movie to city hall. Persuaded by the precedent and the attorney's line of reasoning the city council voted to prohibit the movie's showing; only one member opposed the ban. But as insurance against its showing the city needed a court injunction restraining theatre operators. As the urging of the NAACP, the city attorney requested an injunction. This request touched off litigation that ultimately backfired, as a municipal court decision allowed the movie to be shown on the grounds that it did not violate the 1907 ordinance. ${ }^{22}$

Hence, the Des Moines NAACP lost its first and perhaps one of its more important legal battles. Yet it still gained muchneeded city-wide publicity and demonstrated that the NAACP could mobilize a considerable amount of support. One student of Negro history, Herbert Aptheker, concluded that while the effort proved unsuccessful, the Des Moines branch members discovered more friends and supporters than they realized, and the movie had a shorter run than scheduled. ${ }^{23}$

The case also helped black NAACP attorneys sharpen their skills for future legal battles. As members of the grievance committee, these attorneys investigated and reported to national NAACP leaders all forms of racial discrimination in Des Moines. Locally and nationally the NAACP attempted to publicize these findings and pressed to end all discriminatory practices. One local report attacked theatre operators who segregated audiences, and committee leaders issued a formal protest to the city. The committee members urged the city council to pass a resolution "prohibiting the continuance of this pernicious practice." The protestors proscribed the practice of "anti-Negro exhibitions and segregation in the theatres." Little if anything resulted from this appeal; the city council failed to take heed of this protest and demand. ${ }^{24}$

\footnotetext{
${ }^{22}$ Brown, "History of the Des Moines Branch," p. 3; Bystander, 28 January 1916, p. 1; Ibid., 28 April 1916, p. 1; Ibid., 12 May 1916, p. 1.

${ }^{23}$ Aptheker, Documentary History, p. 161.

${ }^{24}$ Bystander, 4 March 1915, p. 1; Ibid., 7 May 1915, p. 1; Memorandum, undated, RNAACP.
} 
Members of the grievance committee tried a different protest approach when they organized a large gathering to magnify a protest in 1920. Pearl DeJarnette, an assistant attendance officer for the city public schools, wrote and circulated a proposal to the board of education calling for the complete segregation of the public schools and suggesting that the eight hundred Negro students in the city schools attend one school. An NAACP committee hastily united the DeJarnette opponents and organized a demonstration. The subsequent gathering so impressed one Bystander writer that he called it a "monster mass meeting of Negro citizens." 25 About one thousand persons, mostly blacks, filled the St. Paul's African Methodist Church in response to the call by NAACP president Elbert Hall. The convocation opened with what the Bystander called "stirring addresses" by several black leaders. Grievance committee head W. H. Lowery proposed several resolutions. The first questioned the practicality of DeJarnette's proposal for two reasons: one, the school building she recommended for Negroes contained only eight rooms, insufficient for eight hundred students; two, the proposal contradicted Iowa's Civil Rights Act of 1884 . The second resolution hinted that DeJarnette's proposal was the board of education's response to an NAACP request for the Independent School District of Des Moines to hire Negro instructors in proportion to the number of Negro students. If such was the case, Lowery insisted that it was entirely unsatisfactory to the black citizens in the district. Resolution three pursued the issue of hiring Negro teachers. Whereas in other large cities around the country there were Negroes on the city payroll (Chicago, Cleveland, and New York), there were none in Des Moines, the resolution asserted. Moreover, Lowery used the attendance figures provided by the city to point out that in at least one public school, half the students were black, and in another, forty percent were black. This evidence, Lowery reasoned, justified the hiring of Negro teachers. The meeting's participants unanimously accepted these

${ }^{25}$ Bystander, 6 March 1920, p. 1; Des Moines Register and Leader, 3 March 1920 , p. 2. 
The Annals of Iowa

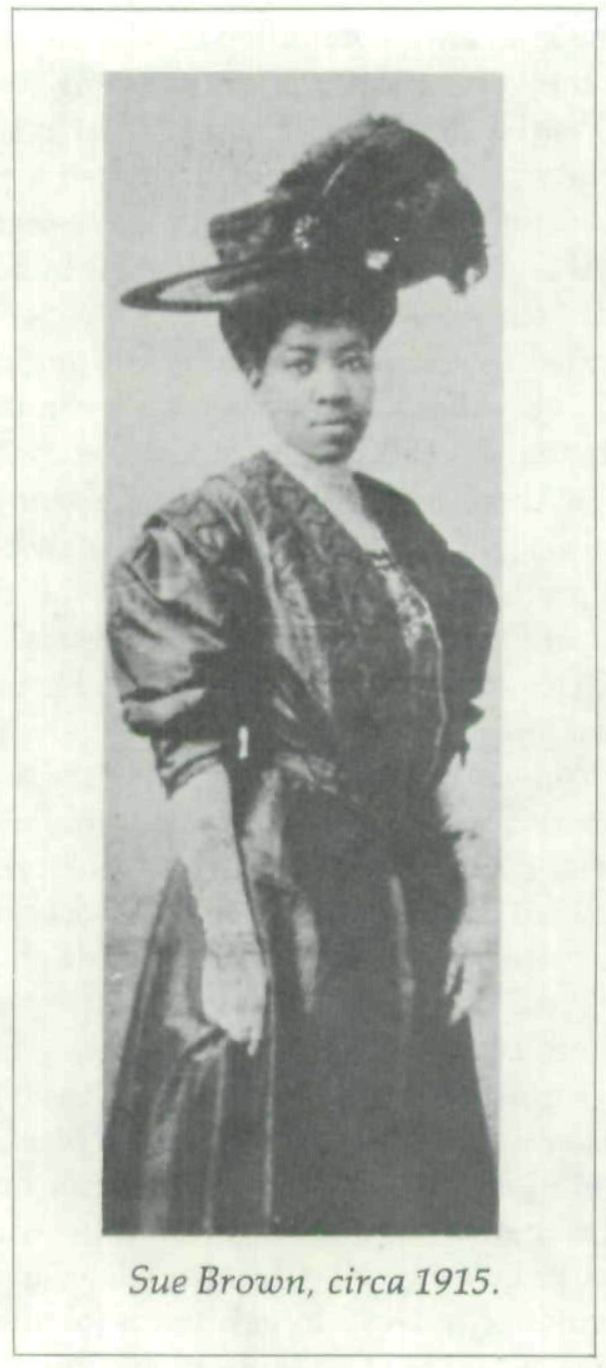

resolutions and adopted them for presentation in the form of a public protest.

Board of education members apparently did not intend to create a separate school as the NAACP suspected. But even if board members were not plotting segregation and the NAACP had overreacted, the resolution issued by the Association carried enough force to elicit an official response from the city's educational policymakers. The board members and the city 
superintendent wrote to the NAACP stating that official policy did not include segregation of black children; the board insisted DeJarnette's suggestion represented that of a single officer only and should be properly interpreted as such. Also a city board of education election was in progress and the issues the candidates discussed did not include segregation. ${ }^{26}$

The NAACP followed through in its agitation for Negro teachers, but its request fell upon deaf ears. In 1921 Hall wrote to Mary White Ovington in New York requesting help. He said that the Des Moines branch would continue to press for the hiring of Negro teachers, but it needed statistics showing city officials that other cities hired blacks in their school systems as the NAACP had claimed in its resolution during the DeJarnette affair. Hall also told Ovington that the local branch had the support of the "largest white church in Iowa." Still, from the NAACP's viewpoint nothing positive resulted from Hall's efforts nor from those of his immediate successor. By 1930 the Des Moines branch still worked for this goal with no success. Another factor that contributed to stopping this effort (besides white reluctance to have black teachers) was that some black leaders favored separate schools. ${ }^{27}$

Despite the losing effort in this Jim Crow fight, the NAACP battled on other fronts, chiefly through legal action rather than protest meetings. The early 1920 s saw the Association's most important victories. In 1920, for example, the Association became involved in a residential segregation case. Dorothy Quail, a light-skinned black woman, agreed to purchase a home in an exclusively white neighborhood. After signing the contract the real estate agent discovered his "mistake" and sought to cancel the agreement, thereby denying Quail the home she purchased. The previous owner initiated a law suit attempting to secure an injunction to prevent the sale. He claimed he had made an oral agreement with his real estate agent to sell only to whites. ${ }^{28}$

${ }^{26}$ Bystander, 6 March 1920, p. 1; Des Moines Register and Leader, 1-9 March 1920.

${ }^{27}$ Hall to Ovington, 22 March 1921, Box G-68, folder 1, RNAACP.

${ }^{28}$ Bystander, 3 February 1921, p. 1. 
The NAACP seized the initiative and provided Quail with legal assistance. The local branch bolstered its defense funds to defray all legal expense. To the Negro community this became an important case; the NAACP viewed it as a challenge to the city's realtors who surreptitiously agreed to keep blacks out of certain metropolitan districts. NAACP attorneys deftly handled the case, arguing that the real estate firm, in ejecting Quail from her home, violated the Fourteenth Amendment to the Constitution as well as the Iowa Civil Rights Act of 1884. The NAACP forces won; the municipal court permitted the sale. The $B y$ stander's editors hailed this victory, but cautioned that more battles over discrimination would follow. ${ }^{29}$

In the summer of 1923 the NAACP tackled another case of blatant segregation. Negroes complained of discrimination at a municipal bathing beach where they were denied the right to swim. S. Joe Brown appealed to the city council, whose members had shown sympathy to past problems faced by blacks. The mayor, supported by the council, introduced and secured the passage of a resolution banning future discriminatory practices at any city bathing beach or park. The national NAACP office commended these efforts. ${ }^{30}$

James B. Morris was branch president during the years of the Quail suit and Brown's protest of the segregated beach, and since 1922 he had been editor of the Bystander. During his stint as head of the Des Moines NAACP, Morris teamed with Volney Diltz, a white state legislator representing Polk County and an Association member, to gain another victory for black Iowans. The state had passed a civil rights statute in 1884 granting Negroes "full and equal enjoyment" of facilities such as inns and barbershops as well as all public conveyances such as trolleys. ${ }^{31}$ But Morris and Diltz believed that the penalty imposed under the law was unrealistically severe and thereby made convictions hard to secure. The law's severity rendered it ineffectual. While

${ }^{29}$ Bystander, 6 April 1920, p. 1; Ibid., 23 April 1920, p. 1.

${ }^{30}$ Walter White to S. Joe Brown, 20 July 1923, Box G-68, folder 1, RNAACP; Des Moines Capital, 27 July 1923.

${ }^{31}$ Laws of lowa, 1884, Ch. 105. 
running for office Diltz promised to introduce a bill reducing the penalty for Civil Rights Act violators. On the surface, Diltz's bill appeared to represent a slackening of the state's concern for protecting the rights of blacks; the proposed legislation actually was intended to achieve an opposite effect. Diltz won election and authored the bill in the 1923 General Assembly. As Morris described it, the amendment "put teeth in the law." The previous version of the bill stipulated that the accused violator must appear before a grand jury and face indictment before standing trial. Under the Diltz amendment the grand jury procedure was waived, eliminating the necessity of an indictment. Morris intimated that the reason so few people had previously received convictions was because "the information has died behind closed doors of the grand jury." ${ }^{32}$

The same year that Diltz and Morris planned the passage of this legislation, a young black woman, Dottie Blagburn, refused to sit in the section of a Des Moines theatre designated for blacks and ushers forced her to leave. The NAACP agreed to support her as plaintiff in a lawsuit. Her attorneys successfully persuaded the all-white jury to issue a guilty verdict against the theatre owners. Official branch correspondence indicated that this marked the first case in which the state of Iowa actually prosecuted and convicted any white for racial discrimination. ${ }^{33}$

The early 1920 s marked an impressive series of victories for the Des Moines NAACP. James Morris served with much skill and success during this time. The secretary of the national organization, Walter White, referred to the "splendid work" achieved by this branch in 1923 . White promised that the Crisis would carry a story praising Des Moines' successes. The following year the NAACP earned another significant victory against segregation. A Council Bluffs chiropractor, Dr. Samuel Barrett, wrote the national branch about a pending bill in the state legislature which purported to forbid marriage between the races.

${ }^{32}$ Morris to Robert Bagnall, undated, Box G-68, folder 1, RNAACP.

${ }^{33}$ William Taylor, secretary of the Des Moines branch, to Robert Bagnall, 20 November 1923, Box G-68, folder 1, RNAACP; Taylor to James Weldon Johnson, 15 December 1923, Box G-68, folder 1, RNAACP. 


\section{The Annals of Iowa}

Three days later President Morris received instructions from the assistant secretary to take steps to defeat this "iniquitous legislation." Morris and his successor, Dr. J. Jefferson, lobbied for the bill's defeat. With help from Diltz, the law never passed. In fact, a similar bill introduced a few years later also failed. ${ }^{34}$

S UE BRown, Association president from 1925 to 1930, could boast of impressive gains by 1928. In addition to reporting the defeat of three bills designed to ban weddings between a black and a white, Mrs. Brown wrote the national office concerning three state convictions of civil rights violations. She also reported to the national office that her husband's bid for municipal judge, although ultimately unsuccessful, received a surprising amount of support from the white community. A success she did not officially report was the dissipation of the city's Ku Klux Klan outbursts after the mid-1920s. However, to the black community's chagrin and disappointment, previously received support from the public leveled off. By 1930 the Association's grievance committee was reporting the same kinds of problems that blacks had faced in 1915 when the Des Moines NAACP formed. The grievances were slight variations on the old theme of discrimination: the discontinuance of a post office in a black-owned drug store, the discharge of Negro city hall employees, and the alleged refusal of a store to serve a Negro customer. ${ }^{35}$

A summary of the NAACP is not complete without a delineation of the transitory victories along with the truly substantive gains that affected the whole Negro population. Court decisions

${ }^{34}$ Walter White to S. Joe Brown, 5 May 1923, Box G-68, folder 1, RNAACP; although the national branch indicated the presence of articles about Des Moines' branch at this time, the July and August issues of the Crisis contain no mention; Dr. Samuel Barrett to national branch, 20 December 1923, Box G-68, folder 1, RNAACP; Assistant secretary, national branch to James Morris, 23 December 1923, Box G-68, folder 1, RNAACP; Sue Brown to NAACP president and delegates to the 19th annual NAACP conference, Los Angeles, 1928, Box G-68, folder 1, RNAACP.

${ }^{35}$ S. Joe Brown to Bagnall, 20 April 1928, Box G-68, folder 1, RNAACP; 
suggested that black persons in Iowa and Des Moines enjoyed the same basic rights as whites. But discrimination still persisted. Blacks still constituted too few numbers to secure or sustain any political influence despite the NAACP's popularity, and social barriers remained as firm as ever.

One lasting NAACP accomplishment of the 1920s, as important as any legal precedent, was the added confidence its actions engendered among black leaders. Brown, Morris, and their colleagues fought with considerable skill in the courtrooms of the city and enjoyed a high status in black society. Brown was perpetually involved in a variety of club and church related activities, almost always assuming a leadership role. Morris, too, followed a similar course: he edited the Bystander, was involved in Republican politics, and practiced law.

Whites played a crucial role in making the NAACP the first genuinely efficacious organization for all blacks. Harvey Ingham and Volney Diltz headed the list of whites in the organization. Although at least two governors and other prominent white members participated sparingly, their very endorsement and membership aided in enhancing the Association's local prestige and served to give it much needed respect. Still, the impact of the prestigious membership proved a minimal influence on the bread-and-butter issue of employment. Competition for jobs during the 1920s in Des Moines was an important factor in the mounting racial tension of the period. Many blacks left Des Moines for such cities as Milwaukee and Chicago in search of better job opportunities. ${ }^{36}$

The Des Moines Interracial Commission articulated its solution to this increasing tension in a document promulgated in 1925. (The Commission, composed of prominent local black

Brown to Bagnall, 26 March 1928, Box G-68, folder 1, RNAACP; Bystander, 23 July 1930, p. 1.

${ }^{36}$ Author's interview with James B. Morris, Des Moines resident (deceased), 20 October 1977. 


\section{The Annals of Iowa}

and white leaders, had formed the year before as part of a national body whose purpose was to promote interracial cooperation.) The organization's "Desiderata of the Des Moines Negroes" contained the following objectives:

1. The abolition of separate bathing beaches and separate everything else supported by public taxation.

2. The abolition of discrimination in the buying and renting of property.

3. The abolition of segregation in hotels, restaurants, theatres and other places of public accommodation.

4. The abolition of the custom that has prevailed in Polk County for twenty years of excluding all Negroes from the Grand Jury lists.

5. Representation in proportion to our population in all city and county labor and office work, with a definite program for the interviewing of employers of labor and the heads of the labor unions to the end that more Negroes may be employed in other than menial jobs; and that the labor unions may take a fairer attitude toward Negro mechanics of the respective trades.

6. Several more carriers and at least one clerk in the Des Moines Post Office.

7. A member in the attendance department of the Des Moines Public Schools; and at least one teacher in those schools which we furnish about $50 \%$ of the pupils as we do in Franklin and Logan Schools.

8. Better attendance of white people upon Negro meetings for which an invitation is extended to the general public.

9. More opportunities for Negro speakers to appear before audiences of white people, more especially groups of white children.

10. The introduction of a course in Negro history into the Des Moines Public Schools.

11. At least 200 white men and women to become members of the Des Moines branch of the National Association for the Advancement of Colored People.

12. A fully equipped modern Y.M.C.A. building at 12 th and Crocker Streets. 
13. A fully equipped modern Y.W.C.A. building at 13th and School Streets.

14. A Negro member on the Des Moines Board of Education. ${ }^{37}$

These objectives clearly illustrated acute dissatisfaction on the part of Des Moines blacks concerning their community. These objectives embraced nearly every facet of life in the city, and poignantly demonstrated that much interracial progress was needed even in the face of positive changes created by the NAACP.

The NAACP established important trends during the century's first two decades. The activities of this group created an atmosphere that fostered the growth of a viable black leadership within the white-dominated society. Likewise, black attorneys, especially those who demonstrated specific achievements, gained prestige within their own community. Brown and Morris held leadership positions in almost every club or society in which they were members. Their powerful influence with groups in the black community naturally was an asset in their good rapport with the city's white leaders.

Confidence instilled in black leaders through the NAACP was a contagion that spread eventually over the entire black community. It was a start in the long uphill struggle to win victories over discrimination. In Des Moines the NAACP established a significant precedent for meaningful dialogue between white and black leaders - a dialogue that produced a climate of hope and courage in which intolerable segregation practices came to be effectively challenged and defeated in the years that followed.

${ }^{37}$ S. Joe Brown, S. E. Thompson and James B. Morris, "20 Years of Interracial Work in Des Moines, Iowa: Brief History of Des Moines Interracial Commission," (Des Moines: privately published, 1944), Des Moines Public Library, pp. 2-6; Nels M. Hammer, The Book of Des Moines (Des Moines: City Board of Education, 1947), pp. 354-355. 
Copyright of Annals of Iowa is the property of State of Iowa, by \& through the State Historical Society of Iowa and its content may not be copied or emailed to multiple sites or posted to a listserv without the copyright holder's express written permission. However, users may print, download, or email articles for individual use. 